\title{
DEBT OR PROFIT SHIFTING? ASSESSMENT OF CORPORATE TAX AVOIDANCE PRACTICES ACROSS LITHUANIAN COMPANIES
}

\section{Kundelis, E., Legenzova, R., Kartanas, J.}

Egidijus Kundelis / ISM University of Management and Economics, Faculty of Economics, Arkliu st. 18, Vilnius, Lithuania.Email: egidijus.kundelis@stud.ism.lt

Renata Legenzova / Vytautas Magnus University, Faculty of Economics and Management, S. Daukanto st.28-311, Kaunas, Lithuania.Email: renata.legenzova@vdu.lt

Julijonas Kartanas / ISM University of Management and Economics, Faculty of Economics, Arkliu st. 18, Vilnius, Lithuania.Email: julijonas.kartanas@stud.ism.It

\begin{abstract}
Tax avoidance became a frequently observed practice in a global business environment. Multinational enterprises (MNEs) employ differences between statutory tax rates of their home countries and countries of their subsidiaries, aiming to achieve the effective tax rate being lower than the statutory one. MNEs enable tax avoidance practices via multiple channels, transfer pricing and debt shifting being among the most popular among them. The goal of this article is to evaluate if MNEs operating in Lithuania, a small open economy of Central and Eastern Europe (CEE), are engaging in tax avoidance practices, and if yes, what channel debt shifting profit shifting or both are employed. Our research is built on the data for the years 2010-2018 and analyses 3,563 MNEs and local companies operating in Lithuania. Results of the conducted regression analysis rejected the impact of differences in tax rates between MNEs and their subsidiaries in Lithuania on their leverage. Therefore debt shifting across the sample companies was not evident. On the contrary, analysis of profit shifting evidence among sample companies proved the significant influence of transfer mispricing practices on earnings of Lithuanian subsidiaries of MNEs'. Such results may imply that in Lithuania, corporate tax avoidance of MNEs occurs via the channel of profit shifting rather than debt shifting. We suggest that this is related to the specifics of small economies commonly characterised by lower tax rates, underdeveloped financial markets and lower tax avoidance costs.

Implications for Central European audience: Previous tax avoidance and profit shifting research mainly analysed the United Kingdom, Germany and other large countries in Europe, leaving a gap in research on small economies, especially those in CEE. Lithuania, similar to the other CEE open economies, is competing for attracting foreign investment, which makes it relevant to understand if and how the country's tax system is exploited in the corporate governance practices of MNEs.
\end{abstract}


Keywords: tax avoidance; transfer pricing; multinational enterprises; profit shifting; debt shifting

JEL Classification: H26, G32

\section{Introduction}

Companies try to avoid tax payments for various reasons. Seeking to gain individual benefit by reducing taxes payable causes disadvantage to others, as tax burden shifts to those who cannot avoid payment of taxes. Tax planning is much more evident among multinational enterprises (MNEs) than among domestic companies. Strategies employed and actions taken are commonly referred to as base erosion and profit shifting (BEPS) and aim to achieve effective tax rates being smaller than statutory ones. MNEs have superior opportunities when it comes to avoiding tax. They operate among several countries, each with possibly different statutory tax rates and tax rules, meaning MNEs can choose the most optimal locations of subsidiaries to minimise effective tax rates. Multinational companies are usually large and have superior economic capacity. They might get loans from banks with better conditions. Or, if the financial market is limited in that country, a subsidiary can turn to group companies and get an intercompany loan. Moreover, small and developing countries suffer, especially because of their higher reliance on tax revenue for sustainable growth.

MNEs can realise BEPS through eight different channels: transfer mispricing (exploiting weaknesses in the arm's length principle); debt shifting through intra-company loans; location of intellectual property to low-tax countries; treaty shopping; risk transfer; avoiding a permanent establishment status; locating asset sales in low-tax jurisdictions and making cross-border inversions (Beer et al., 2018). In our study on tax avoidance across Lithuanian companies, we decided to assess profit shifting and debt shifting as two of the most widely used BEPS channels (Heckemeyer \& Overesch, 2017).

MNEs have the ability to shift profits across all countries where subsidiaries are located using both external and/or intra-company debt as well as transfer pricing. Corporate tax avoidance is referred to as profit or debt shifting and other strategies of MNS aiming to achieve the effective tax rate being lower than the statutory tax rate. Numerous studies document tax avoidance to be positively related to debt financing (Huizinga et al., 2008; Malinic et al., 2013; Blouin et al., 2014; Dwenger \& Steiner, 2014; Møen et al., 2018). Empirical studies also demonstrate that MNEs and their subsidiaries use transfer pricing manipulation to shift profits within a group from high-tax to low-tax countries (Clausing, 2003). As discussed in our previous research (Kundelis \& Legenzova, 2019), empirical studies (Hines \& Rice,1994; Huizinga et al., 2008; Lohse \& Riedel, 2013; Dischinger et al., 2014; Casillo-Murciego \& López-Laborda; 2017; de Mooij \& Liu, 2020, etc.) found evidence of the significant yet varying in its scope impact of tax differentials on company's debt shifting and transfer mispricing activities. Previous research on tax avoidance via channels of debt or profit shifting mostly used data from Germany, the UK, France, Denmark and other large developed European countries as well as countries from other regions (i.e. USA, South Africa). 
A number of studies analysing firms in small open economies are very limited, mostly analysing large listed companies (Bartholdy \& Mateus, 2008; Tzioumis \& Klapper, 2012; Malinic et al., 2013). This leaves a gap in the assessment of corporate practices of small open economies represented by openness to trade, no impact on global prices, high sensitivity to external shocks, limited impact on FDI, high capital mobility, fierce tax competition to attract FDI - lower corporate income tax rates, specialised and targeted exports, higher capital intensity and efficiency in firms owned by MNEs, etc. Small open economies of CEE, such as Lithuania, are competing for attracting foreign investment; therefore, it is relevant to understand if and how the tax system of such countries is exploited by MNEs. All this supports our choice of Lithuania as being an interesting object to explore.

In this article, two research questions are raised: 1) how to assess the evidence of corporate tax avoidance across firms operating in a small open economy and 2) which channel - debt shifting or profit shifting (via transfer pricing manipulation) - is preferred by companies operating in a small open economy. To address these questions, the paper aimed to assess if MNEs operating in Lithuania, a small open economy of Central and Eastern Europe (CEE), were engaged in tax avoidance practices, and if yes, what channel they used.

In our research, we followed previous literature by choosing the direct method to test tax incentives for debt shifting and the indirect method - for testing profit-shifting incentives (via transfer mispricing). In general, empirical assessment of tax planning behaviour uses both direct and indirect methods (Casillo-Murciego \& López-Laborda, 2017), the indirect method being more often used in cases when data is limited or unavailable (Dischinger et al., 2014). In this study, the indirect method was based on Hines and Rice (1994), as firm-level information on intra-firm transfer prices for Lithuanian companies was unavailable. The current study continues our previous research of corporate tax avoidance in Lithuania (Kundelis \& Legenzova, 2019; Kundelis et al., 2021). Our study is in line with Nicolay et al. (2017), who was one of the first to construct an empirical study employing two empirical models: profit shifting via transfer pricing manipulation and debt shifting to test the substitution between those two channels. Yet, to our knowledge, this is the first paper to test for debt shifting and transfer mispricing in a small economy context that incorporates not only both channels but also direct and indirect assessment methods into a single study.

\section{Tax bias of debt financing}

Debt financing is an essential part of today's economy: corporations take loans or issue debt instruments as a method to reach greater efficiency and to maximise value creation for shareholders. Generally, existing bias towards debt financing is explained by at least a few reasons: interest payments provide a tax shield (trade-off theory) and can serve as a tool to control free cash flows within the firm (agency theory). Domestic firms can only choose external loans. In contrast, by having access to several tax regimes in different economies, MNEs can exploit international tax differences and choose optimal internal financing strategies. This brings a competitive advantage to MNEs because internal debt is cheaper and doesn't affect the overall liquidity of the group. Thus, agency costs also do not arise (Haufler \& Runkel, 2012). Moreover, the parent company of MNE has the ability to set guarantees on third party loans and share part of the bankruptcy costs with the government. The advantage of MNE's internal debt market is relatively stronger in countries with expensive 
external financing - where less creditor protection is present and financial markets are underdeveloped. But internal debt may also be used to maximise MNE benefits by taking off subsidiaries' earnings via debt shifting.

Generally, studies investigating the relationship between corporate debt and tax avoidance practices of such companies can be classified as single-country studies (Dwenger \& Steiner, 2014; Kazmierska-Jozwiak et al., 2015; Merlo et al., 2020) or cross-country studies (Huizinga et al., 2008; Blouin et al., 2014; Møen et al., 2018, de Mooij \& Liu, 2020). The majority of them employ regression models and study the relationship between the debt and the tax measures, and controlling for the other variables. Cross-country studies are often criticised for integrating data of different tax systems and other unobserved variables into a single study, thus potentially comparing non-comparable data, while single-country studies do not have this problem (Heider \& Ljunggvist, 2015). However, single-country studies exploit oneoff tax-related shocks, which affect all firms, so there is no control group to separate the impact of the taxes from other variables (i.e. crisis, new regulation, drop-in interest rates).

In more recent studies, Merlo et al. (2020) identified that higher corporate income tax rates and stricter thin cap rules negatively affect location choices of German MNE. Contrary, the authors specify that lower corporate income tax rates and more relaxed thin cap rules positively affects the probability of choosing a given location to set up the first subsidiary. De Mooij and Hebous (2017) also investigated whether and how thin-cap rules affect corporate leverage; they also extend by exploring the effects of thin-cap rules on a firm's financial distress risk. Their findings show that the design of the rules makes a difference - the thincap rules targeted at related-party debt have no significant impact on (external) consolidated debt ratios; they have no effect on a firm's financial distress risk. In contrast, the thin-cap rules applying to all types of debt (internal and external) reduce the consolidated (external) debt-asset ratio and reduce the probability for a firm to be in financial distress; therefore, such type of thin cap rules can be recommended to address the macroeconomic stability concerns. De Mooij and Liu (2020) used panel data on multinational companies in 34 countries during 2006-2014 to investigate thin cap rules effect on investment. They document the adverse effect, which magnitude can be large, dependent on the corporate tax rate and the tightness of the safe-haven ratio. The negative investment effects from thin cap rules can make governments more reluctant to introduce them unilaterally or encourage them to adopt more lenient regulations. Leszczylowska and Meier (2021) investigated the effect of the introduction of thin cap rules in 2012-2017 in seven European countries (Spain, Portugal, Greece, Finland, Norway, Slovakia, Iceland). This one of the few studies which investigate the effect of a new type of thin cap rule - earnings stripping rules aimed at restricting interest deductibility based on EBITDA threshold - uses quite recent data and separates between investments into tangible and intangible assets. Findings prove that these rules adversely affect corporate investment. The adverse effect is observed when the rules restrict total debt as well as when they apply to related-party debt. But the magnitude of this effect varies across countries and types of investment - in tangible and intangible assets. The authors argue that thin cap rules restricting related-party debt impact less tax aggressive firms that do not have opportunities to substitute internal leverage for external debt; such firms are more sensitive to the introduction of thin cap rules and, in response to the rules, lower investment in the tangible assets. 
The majority of empirical studies document the positive link between taxation and a firm's leverage which is strong evidence of trade-off theory. Such studies mostly cover large countries like USA, Germany, European countries or OECD members and their foreign subsidiaries because of the availability of better-quality data.

A number of studies analysing firms in small open economies are very limited (Malinic et al., 2013; Mardan, 2017); they mostly analyse (large) listed companies. Also, studies provide evidence that MNEs have a tax advantage over domestic-owned firms, i.e. more involved in tax avoidance via debt (Møen et al., 2018). This research addresses the above-mentioned limitations. It analyses firms in a small open economy, i.e. Lithuania, and addresses the link between tax avoidance and leverage in MNE-owned firms versus domestic-owned firms.

As statutory corporate income tax (STR) rate is relatively low in small economies, trade-off theory implies that firms in small economies facing lower tax rates use less debt. Some authors find the overall corporate leverage ratio to be significantly lower for MNEs which collects the majority of their profits in low-tax countries (Faulkender \& Smith, 2016). Instead, subsidiaries in low-tax countries may act as providers of internal debt for other companies in the group. On the other hand, the small economy's financial market is generally rather underdeveloped for MNEs to establish a debt distribution channel from here. Also, considering the recently imposed BEPS countermeasures on debt financing, debt may not be the main channel of tax avoidance, as also suggested in other empirical studies (Buettner \& Wamser, 2013). Alternatively, corporations may engage in tax avoidance via transfer pricing manipulation (Eden, 2012).

\section{Transfer mispricing as a tool for profit shifting}

Transfer pricing is defined as rules and practices for pricing transactions across companies under common ownership. It enables MNEs to manage the prices which the parent company and/or its subsidiaries charge for intra-group transactions taking into consideration statutory tax rates of operating countries aiming to shift profits from high to low tax countries (de Mooij \& Liu, 2020). The empirical research of tax-motivated transfer mispricing splits into two strands. One strand of empirical studies was firstly presented by Hines and Rice and assesses indirect overall expected results of tax avoidance (Hines \& Rice, 1994; Lohse \& Riedel, 2013). Researchers claim that MNEs try to hide BEPS activities from the public and transfer mispricing is not directly observable because of confidentiality policies surrounding firm data and uncertainty of the 'arm's length principle (Eden, 2012). Therefore, the researchers indirectly test evidence of the profit shifting via transfer mispricing by assessing whether tax incentives reduce the reported operating pre-tax profitability of lower-tax subsidiaries of MNEs. For example, Huizinga et al. (2008) show that a $1 \%$ lower tax rate differential in absolute terms is related to $1.43 \%$ (1.43 semi-elasticity) increased profitability of European firms. Using panel data of European companies for 1999-2009 and controlling for subsidiaries location, Lohse and Riedel (2013) found even smaller effects than those reported by Huizinga et al. (2008). Their findings suggest that a $1 \%$ higher tax rate is related to $0.4 \%$ reduced profitability. Analysis of tax avoidance in Spain for the period 2005-2014 revealed that the tax rate differences between Spain and foreign countries vary by $1 \%$, reported profits of Spanish subsidiaries to vary by around $2.7-3 \%$ and prove that reported profits are influenced by taxes (Casillo-Murciego \& López-Laborda, 2017). Using 2003-2011 
panel data of European MNEs subsidiaries, Loretz and Mokkas (2015) found that a 1\% decrease in the tax rate increases post-tax profitability (excluding financial profits) by up to $0.06 \%$. They also indicated that financial profits and losses are particularly responsive to taxes. Dowd et al. (2017), using tax returns data of US MNEs over the period 2002-2012, found a significant non-linear effect of tax differential that points to more shifting into tax havens.

Johannesen et al. (2016) used data of MNEs and their subsidiaries in 142 countries (from ORBIS), including 92 developing counties and concluded that less developed countries are more exposed to cross-border profit-shifting. Using European data de Mooij and Liu (2018) studied the impact of introducing or tightening transfer pricing regulations and found that such regulations have a negative and significant effect on MNEs investment in fixed assets. The introduction of such regulations reduced MNEs fixed investment by 15 per cent, compared to investment by domestic companies. On the other hand, some researchers, for example, Buettner et al. (2018), using data for German MNE affiliates, did not report a significant impact of tightening transfer pricing regulations. Therefore, the evidence suggests profitability be negatively related to the corporate tax rate. In our previous research (Kundelis \& Legenzova, 2019), indirect evidence of profit-shifting behaviour was documented by comparing the effective tax rates between parents and subsidiaries operating Baltic other countries and profits reported by sample companies operating in Baltic countries and showed that decrease of tax differential by $1 \%$, resulted in 2.3 increase in profits reported in Baltics.

Another strand of profit shifting oriented empirical studies provided direct evidence on taxmotivated transfer mispricing. Studies conducted in large countries such as Denmark (Cristea \& Nguyen, 2016), France (Vicard, 2015), the UK (Liu et al., 2017), the USA (Flaaen, 2016) and South Africa (Wier, 2018) proved the relationship between tax rate differentials of MNEs and differences in prices between the arm's-length transactions and the transfer prices in related-party transactions. Empirical estimates of the semi-elasticity of those studies vary due to structural reasons like the different scope of operations, peculiarities of industries, different tax enforcement and administrative capacity. Unfortunately, studies of direct evidence stream cover mostly trade in goods in certain large economies because comprehensive data on arm's length and related party transactions are rarely accessible for smaller economies. Also, the above-mentioned studies do not cover trade in services, which are a substantial part of any modern economy and where it is easier to manipulate transfer prices because comparable transactions are hard to find.

The influence of profit shifting is also assessed on a country level, most commonly using the FDI approach and estimating what are the tax revenue losses due to profit shifting. For example, Janský and Planský (2019) employed an FDI approach and estimated that due to profit shifting, 79 sample countries lost approximately $\$ 125$ billion annual tax revenue while Cobham and Janský (2019), using data from 34 countries, reported $\$ 133$ billion annual tax revenue losses; findings of Clausing (2016) report an $0.48 \%$ average tax revenue loss (\% GDP) across 25 analysed countries.

\section{Research methodology}

Hypotheses. To address the research questions on how to assess the evidence of corporate tax avoidance across firms operating in a small open economy and which channel (debt 
shifting or profit shifting via transfer pricing manipulation) is preferred by companies operating in a small open economy, two hypotheses are formulated and substantiated.

The leverage of a company depends on a substantial number of factors which are supported by several theories developed over time. As documented by some research (Rajan \& Zingales, 1995; Booth et al., 2001), for large economies, dominant by large companies, tradeoff theory is more relevant because such firms are bigger in size, have the larger scale or scope of operations, are more profitable, have more capital assets which can be used as collateral, take interest-bearing debt for investment and grow, and balance benefits of debt tax shield with costs of financial distress. However, those studies mostly cover large countries like USA, Germany, European countries or OECD members (Huizinga et al., 2008; Barion et al., 2010; Buettner \& Wamser, 2013; Blouin et al., 2014; Faccio \& Xu, 2015; Møen et al., 2018), and represent older periods data (1980-2010) when interests rates on debt instruments were higher than were in the last decade. This may be one of the reasons why strong evidence of the trade-off theory was found.

In addition, the studies of this stream provide evidence that MNEs have a tax advantage over domestic-owned firms, i.e. MNEs are more involved in tax avoidance via debt (Møen et al., 2018). Also, large multinationals save up to $60 \%$ of corporate tax expenses compared to domestic competitors, and this effect is even stronger in developing markets (Egger et al., 2010), meaning that impact of corporate tax avoidance activities via debt shifting channel in small open economies may be relatively more significant. MNEs having subsidiaries in small open economies with moderate or low tax rates may rely on debt shifting channel via the provision of lending via financing or treasury firms established in very low or zero-tax economies (havens) (Desai et al., 2004; Huizinga et al., 2008; Egger et al., 2010; Lee et al., 2015; Merlo et al., 2020).

Summarising the above-mentioned, the following hypothesis was formulated:

$\mathbf{H}_{1}$ : In a small open economy, corporate tax avoidance has a significant impact on the leverage of subsidiaries of MNEs but not on the leverage of local firms.

Generally, debt shifting can be performed from a lower tax country to a higher tax country. However, if the statutory tax rate in small open economies is relatively moderate or low, then according to the trade-off theory, firms will use less debt. Then MNEs are able to choose the alternative channel of tax avoidance - transfer mispricing (Saunders-Scott, 2015; Nicolay et al., 2017), while such channel is not available for local firms. Due to specifics of small open economies (lower tax rates and underdeveloped financial markets), corporate tax avoidance in subsidiaries of MNEs may occur not via financial leverage but via alternative profit shifting channels of transfer pricing manipulation. Hence, the second hypothesis was formulated as follows:

$\mathbf{H}_{2}$ : In a small open economy, corporate tax avoidance has a significant impact on the performance of subsidiaries of MNEs, which can be treated as evidence of profit shifting via transfer pricing manipulation, but not on the performance of local firms.

Models. In this study, we employed panel regression analysis with firm fixed effects and constructed two main models - one to test debt shifting and another - to explore profit shifting via transfer mispricing. The firm fixed effects model is selected based on previous research 
(de Mooij \& Hebous, 2017; Nicolay et al., 2017) and due to several reasons. First, Hausman Chi-square tests performed in all the models revealed a correlation between the unobserved unit of observation's specific random effects and the regressors. Secondly, the fixed effects model was chosen to address the limitation of the OLS estimation (a large number of companies, standard errors are not valid, i.e. $t$-, F- Wald-). Thirdly, the fixed-effect model allowed to capture time-invariant characteristics that are unique to firms and not correlated with other firm individual characteristics.

Model 1 measures the impact of corporate tax avoidance on debt shifting and is presented in equation (1). The main dependent variable used in debt shifting Model 1 is the Leverage ratio which is calculated as the firm's total debt (short-term debt plus long-term debt) to total assets, as by Frank \& Goyal (2009).

$$
\text { Leverage }_{f, t}=\beta_{0}+\beta_{1} \text { Tax }_{f, t}+\beta_{k} \text { Firm_controls }_{f, t}+\beta_{j} \text { Industry_controls }_{i, t}+\varepsilon_{f, t} \text {. }
$$

Model 2 aims to test the existence of profit shifting via transfer mispricing and is presented in equation (2). In model 2 , the main dependant variable is earnings before taxes (EBT).

$$
E B T_{f, t}=\beta_{0}+\beta_{1} \operatorname{Tax}_{f, t}+\beta_{k} \text { Firm_controls }_{f, t}+\beta_{j} \text { Industry_controls }_{i, t}+\varepsilon_{f, t} .
$$

In both models, $f$ represents individual companies in the data sample, $i$-industry, $t$-year.

Independent variable. Both models employed effective tax rates over the past three years (ETR3) as the main tax measure. For the robustness check, we also tested both Models with two additional tax measures - book-tax difference (BTD) and cross-country tax differential (TaxDiff).

In this research, ETR3 is a 3-year average calculated by dividing tax expenses of $f$ individual companies by profit before taxes of respective companies. ETR was also used in previous research (Rego, 2003; Dwenger \& Steiner, 2014). We decided to use ETR3 instead of a simple ETR to ensure higher stability of the data and, therefore, more robust results. Like previous findings (Chen et al., 2010), our expectations are to see negative ETR3 coefficients.

We also calculate the standard deviation of the effective tax rate (stdevETR) to assess how sensitive the operations of sample companies are to taxes. The relationship of stdevETR to the level of debt could be discussed from the perspective of financial distress and therefore need to attract additional (debt) financing. In both our models, we expect that the relationship between leverage and stdevETR will be positive.

Two additional measures of taxes were used for the robustness check. Book tax difference (BTD) and cross-country tax differential (TaxDiff) were calculated similarly to our previous research (Kundelis \& Legenzova, 2019) as they proved to be available for use in a single country environment. We calculated BTD for each company as a difference between tax base (calculated as tax expenses divided by the statutory tax rate) and reported EBT and then divided the result by sales revenues. Another tax measure used for robustness check TaxDiff was calculated as a difference between tax rates of the parent company and its Lithuanian subsidiary. In this respect, in the testing of both models' the data sample excluded domestic companies. 
Control variables. As both models are centred around the effect of corporate taxation on leverage or pre-tax profitability, it may omit a lot of other factors. To make the model more accurate and to allow more profound result interpretations in this study, we included firm-level and industry-level variables into our models, as presented in Table 1. Control variables were mainly constructed according to the methodology of Huizinga et al. (2008) and Møen et al. (2011).

Table 1 | Description of control variables

\begin{tabular}{|c|c|c|c|}
\hline $\begin{array}{l}\text { Set of } \\
\text { variables }\end{array}$ & Variable & Calculations & $\begin{array}{l}\text { Expected } \\
\text { influence }\end{array}$ \\
\hline \multirow{15}{*}{ Firm-level } & Assets & $\ln ($ Assets $)$ & + \\
\hline & & $\ln (\text { Assets })_{t}$ & \\
\hline & Growth & $\overline{\ln (\text { Assets })_{t-1}}$ & $+/-$ \\
\hline & Employees & $\ln ($ Employees $)$ & + \\
\hline & & $E B I T$ & \\
\hline & Prof_index & $\ln (\overline{\text { Assets }})$ & $+/-$ \\
\hline & & Fixed assets & \\
\hline & Tangible & Assets & $+/-$ \\
\hline & & Intangible assets & \\
\hline & Intangible & $\overline{\text { Assets }}$ & - \\
\hline & & short - term assets & \\
\hline & Lıquıdıty & $\begin{array}{c}\overline{\text { Short }- \text { term liabilities }} \\
\text { Gross profit - EBIT }\end{array}$ & + \\
\hline & AdminCost & Revenue & $+/-$ \\
\hline & FinRisk & Z-score (provided before) & - \\
\hline & ind_Growth & & $+/-$ \\
\hline \multirow{3}{*}{$\begin{array}{l}\text { Industry- } \\
\text { level }\end{array}$} & Total ind_Leverage & Average of $f$ total leverages in $i$ & \\
\hline & Short term ind_Leverage & Average of $f$ short term leverages in $i$ & + \\
\hline & Long term ind_Leverage & Average of $f$ long term leverages in $i$ & \\
\hline
\end{tabular}

Source: authors' compilation based on Huizinga et al. (2008) and Møen et al. (2011).

Dummy variables were used to divide observations into two sub-samples based on corporate global ultimate owner location. When data on the latter was missing, the intermediate parent owner location was chosen instead. This dummy was employed to examine the differences depending on whether the ultimate owner of a firm is based in Lithuania or abroad and to allow interpretation of results coming from domestic versus multinational based corporations. Another dummy variable represented profitable firms and was used for the calculation of earnings ratios.

Data sample. Similar to our previous study (Kundelis \& Legenzova, 2019), research data was constructed from annual firm-level data reported in the Amadeus database. The data represented data on industry, ownership structure (foreign or local) as well as financial data, all of which were used to construct variables that were later modelled. Purposive sampling 
was employed, and all available companies that (i) were incorporated in Lithuania; (ii) had annual operating revenue greater than 1,000 EUR during each of the covered 9-year period, and (iii) had annual operating revenue greater than 1 million EUR for at least 4 out of selected nine years were included in the sample via extraction from Amadeus database. Also, consolidated accounts were not included to avoid double integration of data and to allow comparison of foreign and domestic owned subsidiaries. The initial data set included 3,789 firms operating in Lithuania. Additional (iv) text filters and manually reviewing exported data in Excel eliminated 160 non-profit seeking entities and a few repeating observations. Further data analysis revealed an issue of missing data on the owner country. Additional data collection in the Amadeus database (and applying other search methods) allowed us to add owner information for more than 950 corporations. So, for the model testing, our data sample was constructed of 32,065 observations for 3,563 companies, of which 780 were MNEs (representing $13 \%$ of all foreign firms in Lithuania) and 2,783 local firms (representing $3 \%$ of all local firms in Lithuania; data on domestic groups is unavailable).

\section{Results}

\subsection{Descriptive statistics}

While comparing median values of foreign-owned and domestically owned firms, a few main differences can be noted (Table 1). First, MNEs in the sample have median revenues of E5.5 million, which is 1.97 times higher than local firms with Eur 2.8 million. Looking further, differences in income is least pronounced (1.75 times) when comparing gross profits: MNE equal to Eur 992 thousand, domestic firms equal to Eur 566 thousand. Final (net) income is once again twice higher in multinational affiliates (Eur 121 thousand compared with Eur 61 thousand). The remaining majority of financial data is also roughly two times higher in foreign firms with few following exceptions. Multinationals have 4.5 times more intangible assets, while tangible assets are 1.4 times lower compared with domestic firms. Second, the median of non-current liabilities MNEs is three times lower than that of local firms. Equity is slightly greater (by 35\%) in MNEs, while the number of employees is basically the same. This implies that foreign firms in the sample are significantly larger, and it can be assumed they have more opportunities for debt and profit shifting than local ones. On the other hand, financial data in multinational firms' samples have wider distribution or is situated further from the mean: average standard deviation is twice greater compared to Lithuanian subsample. The higher degree of variance amongst MNE observations and smaller sample size may imply more outliers and lead to less accurate results.

Results of the Total debt ratio (TDR) are almost similar in both sub-samples (21-23\%), but MNE firms show slightly smaller leverage (21\%), which may be acceptable considering low tax rates in Lithuania. Also, foreign firms have a higher portion of the short-maturity debt (43.5\%) than local firms (35.4\%), indicating that short-term debt financing is used as a tool to discipline the managers under agency cost theory. $91 \%$ of cases of MNEs subsample have a negative tax rate difference. This shows that in Lithuania, tax rates are lower than in foreign shareholder countries and may give grounds for profit shifting but allow assuming the absence of debt shifting. To check for multicollinearity, a correlation matrix was constructed. The correlation matrix indicates the strongest correlation (around 0.7) between Assets and 
$E B I T, E B T$. In addition, it is also quite strongly correlated with Employees (0.56) as both measures firm size.

Table 2 | Summary of descriptive statistics

\begin{tabular}{|c|c|c|c|c|c|c|}
\hline & $\begin{array}{l}\text { Mean } \\
\text { (all) }\end{array}$ & $\begin{array}{c}\text { Mean } \\
\text { (domestic } \\
\text { owned) }\end{array}$ & $\begin{array}{c}\text { Mean } \\
\text { (foreign } \\
\text { owned) }\end{array}$ & $\begin{array}{l}\text { Median } \\
\text { (all) }\end{array}$ & $\begin{array}{c}\text { Median } \\
\text { (domestic } \\
\text { owned) }\end{array}$ & $\begin{array}{l}\text { Median } \\
\text { (foreign } \\
\text { owned) }\end{array}$ \\
\hline \multicolumn{7}{|l|}{ In EUR thousands } \\
\hline Operating revenue & 11,204 & 8,194 & 22,415 & 3,124 & 2,788 & 5,494 \\
\hline EBIT & 564 & 400 & 1,182 & 122 & 107 & 226 \\
\hline EBT & 543 & 388 & 1,128 & 112 & 98 & 207 \\
\hline Taxation & 93 & 67 & 186 & 19 & 16 & 37 \\
\hline EAT & 452 & 322 & 941 & 92 & 80 & 170 \\
\hline Intangible assets & 257 & 50 & 1,037 & 1 & 0 & 1 \\
\hline Tangible assets & 3,459 & 3,138 & 4,666 & 333 & 343 & 279 \\
\hline Total assets & 8,099 & 6,591 & 13,768 & 1,882 & 1,706 & 3,029 \\
\hline Shareholders'funds & 4,191 & 3,693 & 6,064 & 855 & 807 & 1,165 \\
\hline Long term debt & 2,303 & 1,709 & 4,137 & 228 & 261 & 88 \\
\hline Short term debt & 1,393 & 1,288 & 1,682 & 102 & 121 & 30 \\
\hline Number of employees & 88 & 77 & 129 & 37 & 37 & 38 \\
\hline \multicolumn{7}{|l|}{ In ratios } \\
\hline$T D R$ & 0.224 & 0.228 & 0.213 & 0.173 & 0.183 & 0.126 \\
\hline$S D R$ & 0.084 & 0.081 & 0.092 & 0.03 & 0.037 & 0.007 \\
\hline$L D R$ & 0.132 & 0.132 & 0.131 & 0.063 & 0.073 & 0.02 \\
\hline LNEBIT & 5.06 & 4.89 & 5.721 & 5.079 & 4.935 & 5.773 \\
\hline LNEBT & 4.933 & 4.757 & 5.62 & 5.002 & 4.851 & 5.718 \\
\hline LNEAT & 4.73 & 4.549 & 5.442 & 4.84 & 4.686 & 5.566 \\
\hline$R O E$ & 0.226 & 0.211 & 0.286 & 0.145 & 0.136 & 0.189 \\
\hline$R O A$ & 0.099 & 0.096 & 0.11 & 0.068 & 0.065 & 0.081 \\
\hline ETR & 0.15 & 0.14 & 0.187 & 0.15 & 0.15 & 0.152 \\
\hline ETR3 & 0.15 & 0.141 & 0.184 & 0.15 & 0.15 & 0.152 \\
\hline$B T D$ & 0.006 & 0.007 & 0.002 & 0 & 0 & -0.001 \\
\hline stdevETR & 0.168 & 0.137 & 0.283 & 0.04 & 0.029 & 0.038 \\
\hline TaxDiff & -0.088 & & -0.088 & -0.09 & & -0.09 \\
\hline Assets & 7.668 & 7.548 & 8.119 & 7.54 & 7.442 & 8.016 \\
\hline Growth & 0.025 & 0.028 & 0.014 & 0.008 & 0.004 & 0.003 \\
\hline Employees & 3.613 & 3.586 & 3.714 & 3.611 & 3.611 & 3.638 \\
\hline Prof_index & -1.888 & -1.718 & -2.383 & -1.702 & -1.546 & -2.169 \\
\hline Tangible & 0.272 & 0.285 & 0.225 & 0.207 & 0.227 & 0.118 \\
\hline Intangible & 0.009 & 0.007 & 0.017 & 0 & 0 & 0 \\
\hline Liquidity & 3.373 & 3.567 & 2.647 & 1.684 & 1.721 & 1.567 \\
\hline AdminCost & 0.21 & 0.213 & 0.199 & 0.163 & 0.163 & 0.162 \\
\hline FinRisk & 4.941 & 5.039 & 4.573 & 3.86 & 3.847 & 3.904 \\
\hline ind_Growth & 0.008 & 0.008 & 0.008 & 0.007 & 0.007 & 0.007 \\
\hline ind_TDR & 0.182 & 0.181 & 0.188 & 0.178 & 0.176 & 0.178 \\
\hline
\end{tabular}

Source: authors

Diagnostics. Diagnostic tests performed did not indicate any multicollinearity issues. Correlation matrices, including all main variables, was constructed to examine some possible issues within the model specifications. 


\subsection{Evidence on debt shifting}

Table 3 presents the results of the debt shifting model for both subsamples - domestic firms and subsidiaries of MNEs. According to the results, subsidiaries of MNEs are affected by each of three tax variables with high significance, except for TaxDiff. In the local firms' sample, taxation does not appear to be significant on leverage.

Table 3 | Regression results of debt shifting model

\begin{tabular}{|c|c|c|c|c|c|c|c|}
\hline $\begin{array}{l}\text { Sample } \\
\text { (by owner) }\end{array}$ & $\begin{array}{l}\text { Domestic } \\
\text { firms }\end{array}$ & $\begin{array}{l}\text { Subsidiaries } \\
\text { of MNEs }\end{array}$ & $\begin{array}{l}\text { Domestic } \\
\text { firms }\end{array}$ & $\begin{array}{c}\text { Subsidiaries } \\
\text { of MNEs }\end{array}$ & $\begin{array}{l}\text { Domes-tic } \\
\text { firms }\end{array}$ & $\begin{array}{l}\text { Subsidiaries } \\
\text { of MNEs }\end{array}$ & $\begin{array}{l}\text { Subsidiaries } \\
\text { of MNEs }\end{array}$ \\
\hline $\begin{array}{l}\text { Tax } \\
\text { variable }\end{array}$ & \multicolumn{2}{|c|}{ ETR3 } & \multicolumn{2}{|c|}{ stdevETR } & \multicolumn{2}{|c|}{ BTD } & TaxDiff \\
\hline Const & -0.0966 & -0.1989 & -0.0206 & -0.103 & -0.0103 & -0.1218 & -0.1891 \\
\hline $\begin{array}{l}\text { Tax } \\
\text { variable }\end{array}$ & $0.0089^{*}$ & $0.0102^{\star \star \star}$ & -0.0063 & $0.0083^{\star \star \star}$ & -0.0403 & $-0.1775^{\star \star \star}$ & -0.3457 \\
\hline Assets & $0.0451^{* * *}$ & $0.0697^{\star \star \star}$ & $0.0339^{\star * *}$ & $0.0487^{\star *}$ & $0.0328^{\star \star *}$ & $0.0629^{\star \star *}$ & $0.0562^{\star \star *}$ \\
\hline Growth & $-0.1038^{* *}$ & -0.0993 & -0.0467 & 0.1182 & -0.0459 & -0.0241 & -0.0059 \\
\hline Employees & $-0.0357^{* * *}$ & $-0.0418^{* \star *}$ & $-0.0238^{* * *}$ & $-0.0355^{*}$ & $-0.0223^{* * *}$ & $-0.0464^{* * *}$ & $-0.0384^{* *}$ \\
\hline Prof_index & $0.0101^{* \star *}$ & $0.0108^{\star * *}$ & $0.0094^{\star \star *}$ & $0.009^{\star * *}$ & $0.0101^{\star \star *}$ & $0.0098^{* * *}$ & $0.0093^{\star \star *}$ \\
\hline Tangible & $0.1872^{* * *}$ & $0.168^{* * *}$ & $0.2094^{* * *}$ & $0.2525^{\star \star *}$ & $0.1878^{\star \star *}$ & $0.2003^{* \star *}$ & $0.267^{\star \star *}$ \\
\hline Intangible & $0.2613^{\star \star *}$ & $0.2043^{\star \star}$ & $0.2021^{* * *}$ & $0.249^{*}$ & $0.2134^{* * *}$ & $0.4137^{\star \star \star}$ & $0.366^{\star \star *}$ \\
\hline Liquidity & 0.0001 & $0.0119^{\star \star \star}$ & 0.0001 & $0.008^{\star * *}$ & 0.0001 & $0.0058^{* * *}$ & 0.0003 \\
\hline AdminCost & $0.081^{* \star \star}$ & $-0.0837^{*}$ & -0.0089 & -0.0253 & -0.0093 & $-0.1221^{\star *}$ & -0.0518 \\
\hline FinRisk & $-0.0127^{\star \star *}$ & $-0.0322^{* \star *}$ & $-0.0154^{\star * *}$ & $-0.0173^{\star \star \star}$ & $-0.0164^{* * *}$ & $-0.0278^{* \star *}$ & $-0.0126^{\star \star \star}$ \\
\hline ind_Growth & $1.0197^{\star \star *}$ & $1.6749^{*}$ & $1.0104^{\star \star *}$ & 1.801 & $1.0394^{\star \star \star}$ & 0.9491 & $2.1033^{\star}$ \\
\hline ind_TDR & $0.2986^{\star * *}$ & $0.1809^{*}$ & $0.2702^{\star \star *}$ & 0.1173 & $0.2844^{\star \star *}$ & $0.2219^{\star *}$ & $0.1996^{\star}$ \\
\hline R-squared & 0.9185 & 0.8847 & 0.898 & 0.8787 & 0.8972 & 0.8781 & 0.9058 \\
\hline
\end{tabular}

Note: ${ }^{*},{ }^{* *}$, and ${ }^{* * *}$ are used to represent significance at the $10 \%, 5 \%$, and $1 \%$ level respectively.

Source: authors

Findings in the subsample of MNEs' subsidiaries contradict the findings of previous research (Chen et al., 2010). Firstly, ETR3 was expected to be negatively related to the level of debt. Instead, it is positive in our model. Secondly, if a firm were to avoid taxes via debt, it should be linked with higher book-tax differences, not lower like the results suggest. Thirdly, stdevETR positively affects leverage as expected, but the observed effect might as well be explained by other factors (apart from incentive to avoid taxes via debt), for example, accelerated depreciation, tax allowances, earnings management. Lastly, tax differences (TaxDiff) appear insignificant as determinants of MNE's subsidiaries debt level, and results are robust across other specifications of the model. In addition to total debt to assets ratio, short term and long-term debt to assets ratios were also tested; no statistically significant results were found. Based on the collected evidence hypothesis $\mathbf{H}_{\mathbf{1}}$ : In a small open economy, corporate tax avoidance has a significant impact on leverage of subsidiaries of MNEs but not on leverage of local firms was rejected as no significant influence in both subsamples were identified. 


\subsection{Evidence on profit shifting}

In the profit shifting model (as presented in Table 4), if compared to the debt shifting model, the leverage and profit variables were switched, and the impact of tax variables on earnings before tax (EBT) was assessed.

Table 4 | Results of profit shifting model

\begin{tabular}{|c|c|c|c|c|c|c|c|}
\hline $\begin{array}{l}\text { Sample } \\
\text { (by owner) }\end{array}$ & $\begin{array}{l}\text { Domestic } \\
\text { firms }\end{array}$ & $\begin{array}{c}\text { Subsidiari } \\
\text { es of } \\
\text { MNEs }\end{array}$ & $\begin{array}{l}\text { Domestic } \\
\text { firms }\end{array}$ & $\begin{array}{l}\text { Subsidiaries } \\
\text { of MNEs }\end{array}$ & $\begin{array}{l}\text { Domestic } \\
\text { firms }\end{array}$ & $\begin{array}{c}\text { Subsidiaries } \\
\text { of MNEs }\end{array}$ & $\begin{array}{c}\text { Subsidiaries } \\
\text { of MNEs }\end{array}$ \\
\hline Tax variable & \multicolumn{2}{|c|}{ ETR3 } & \multicolumn{2}{|c|}{ stdevETR } & \multicolumn{2}{|c|}{ BTD } & TaxDiff \\
\hline Const & $-2.1927^{* \star *}$ & -0.7954 & $-2.8462^{\star \star \star}$ & -0.439 & $-2.9883^{* * *}$ & -0.9163 & $-1.6882^{\star *}$ \\
\hline Tax variable & -0.0862 & $-0.0724^{\star \star *}$ & $-0.5981^{\star * *}$ & $-0.0737^{* * *}$ & $1.4642^{\star \star \star}$ & $0.7904^{\star *}$ & $-2.304^{*}$ \\
\hline Assets & $0.8658^{\star \star \star}$ & $0.8882^{\star \star \star}$ & $0.9565^{\star \star \star}$ & $0.8398^{\star \star \star}$ & $0.9582^{\star \star \star}$ & $0.8808^{\star * \star}$ & $0.8978^{\star \star \star}$ \\
\hline Growth & $3.7788^{* \star \star}$ & 1.1723 & $3.8081^{* * *}$ & 1.1195 & $3.6152^{* \star *}$ & 0.2108 & 0.2315 \\
\hline Employees & 0.0853 & -0.1182 & 0.0578 & -0.0865 & 0.0673 & -0.0594 & -0.0007 \\
\hline$T D R$ & $-0.5822^{\star \star \star}$ & $-0.7198^{\star \star \star}$ & $-0.5731^{\star \star \star}$ & $-0.7153^{\star \star \star}$ & $-0.6119^{* * *}$ & $-0.8104^{\star \star *}$ & $-0.8354^{\star \star *}$ \\
\hline Tangible & -0.2813 & $-0.6921^{\star *}$ & -0.1716 & $-0.6668^{\star *}$ & -0.2504 & $-0.7809^{\star * *}$ & $-0.6025^{\star *}$ \\
\hline Intangible & -0.6132 & $-1.8605^{\star \star \star}$ & -0.9343 & $-1.791^{\star \star *}$ & -0.63 & $-1.7567^{\star \star *}$ & $-1.3594^{* *}$ \\
\hline Liquidity & $-0.0051^{* \star *}$ & $-0.05^{\star * *}$ & $-0.0055^{\star \star \star}$ & $-0.0466^{* * *}$ & $-0.0054^{\star * *}$ & $-0.0453^{* * *}$ & 0.0008 \\
\hline AdminCost & $-1.4699^{* * *}$ & $-2.1116^{* * *}$ & $-1.5718^{\star \star \star}$ & $-2.5387^{* * *}$ & $-1.4524^{\star \star *}$ & $-2.3661^{* * *}$ & $-2.4885^{\star * *}$ \\
\hline FinRisk & $0.1744^{\star \star \star}$ & $0.1518^{\star \star *}$ & $0.1783^{\star * *}$ & $0.1438^{* * *}$ & $0.1686^{\star \star *}$ & $0.1392^{* * *}$ & $0.1338^{* * *}$ \\
\hline Ind_Growth & 4.2916 & 5.3687 & $6.5643^{*}$ & 7.8722 & $7.4337^{\star \star}$ & 7.2129 & 6.3089 \\
\hline ind_TDR & $-1.121^{\star \star \star}$ & -0.1661 & $-1.2224^{* * *}$ & -0.3065 & $-1.0348^{* * *}$ & -0.2686 & -0.2805 \\
\hline R-squared & 0.8317 & 0.8604 & 0.8281 & 0.847 & 0.8246 & 0.8491 & 0.8346 \\
\hline
\end{tabular}

Note: ${ }^{*},{ }^{* *}$, and ${ }^{* \star *}$ are used to represent significance at the $10 \%, 5 \%$, and $1 \%$ level respectively.

Source: authors

In the case of the profit shirting model, all three tax variables (ETR3, BTD and TaxDiff) demonstrated a significant influence on profit before taxes of Lithuanian subsidiaries of MNEs. According to the results presented in Table 3, ETR3 (including stdevETR) and TaxDiff demonstrated negative coefficients while the coefficient for BTD was positive. A tax measure of TaxDiff (with a negative coefficient of -2.304 , at $10 \%$ significance) indicated that Lithuanian subsidiaries with parent companies from the higher tax rate countries reported significantly higher earnings before tax in Lithuania. The results also showed that companies with a lower effective tax rate (ETR3) demonstrated higher earnings before tax (with a coefficient of 0.0724 , at $1 \%$ significance). On the other hand, a positive coefficient of BTD (of 0.7904 , at $5 \%$ significance) along with other tax measures (i.e. effective tax rate) allowed making expected insights into tax planning practices - the results suggest that MNEs with higher taxes in parent countries engage in practices of taxes avoidance via transfer mispricing and report higher profits in Lithuania. Therefore, hypothesis $\mathbf{H}_{2}$ : In a small open economy, corporate tax avoidance has a significant impact on the performance of subsidiaries of MNEs, 
which can be treated as evidence of profit shifting via transfer pricing manipulation, but not on the performance of local firms is accepted. Our results are similar to a study of Clausing (2009), who examined practices of US parent companies and their subsidiaries in lower-tax countries and found that with a $1 \%$ wider gap of statutory tax rates between parent and subsidiary, the subsidiary shows $0.5 \%$ higher profit rate.

Results of the testing of profit shifting model support literature on effective tax planning (Rego, 2003) and incentives to shift profits from high- to low-tax countries (Eden, 2012; Lohse \& Riedel, 2013; Casillo-Murciego \& López-Laborda, 2017, etc.). In our research, the estimated semi-elasticity of $2.3 \%$ on EBT is stronger than reported in other works, and the effects are very substantial - a $10 \%$ increase in tax difference may explain $€ 78.7$ thousand increase in EBT. The closest results were received by Casillo-Murciego and López-Laborda (2017) 2.74 (Amadeus 2005-2014 Spain entities data) -, and Heckemeyer and Overesch (2017) 1.78 (meta-study). The other studies show significantly smaller influence. For example, Lohse and Riedel (2013) - 0.4 (Amadeus 1999-2009 data) -, De Simone (2016) - 0.74 (Amadeus 2003-2012 data).

\section{Discussion}

Our research adds new evidence to the findings of Nicolay et al. (2017), who assessed debt and profit shifting in a single study. In their research data of 32 countries and 103,714 firms for 2004-2012 proved a significant reduction of profit shifting via transfer mispricing channel after the introduction of transfer pricing rules. The authors interpreted that companies moved from the restricted transfer mispricing channel to unrestricted debt shifting. In addition, the same research also provided evidence of the behaviour in the opposite direction (from debt shifting to transfer misprising). Although in our research, we did not analyse channel shifting behaviour, yet our evidence proved that in a small open economy, profit shifting via transfer mispricing is preferred over debt shifting. Testing of debt shifting assumption revealed that none of the specified tax incentives impacted the leverage of Lithuanian domestic firms. It supports the proposition that local firms mostly can apply for external loans, which incur bankruptcy and agency costs and make debt tax shieldless beneficial (Haufler \& Runkel, 2012).

In addition, statutory tax rates differences between home and foreign parent countries did not prove to make an impact on the leverage of sampled subsidiaries of MNEs. This contradicts the trade-off theory and the results of previous research (Huizinga et al., 2008; Fuest et al., 2011; Møen et al., 2011; Buettner \& Wamser, 2013). However, our findings are in line with the other researchers who claim that taxes do not influence the capital structure of a firm (Harris \& Raviv, 1991; Frank \& Goyal, 2009). A possible explanation might be substantial non-debt tax shields like accelerated tax depreciation or investment relief (Bartholdy \& Mateus, 2008). This goes in line with a highly significant impact of tangible and intangible assets on leverage. But depreciation and other tax attributes are not included in our research due to data limitations in the Amadeus database.

Obtained findings from the application of other tax variables (e.g. ETR3, BTD) contradicted with the predicted direction of impact. This may be explained by low-interest rates, lowinterest expenses, low tax rates, which altogether result in a weak tax savings effect. The alternative explanation might come from our methodological assumptions as we did not follow 
traditional assumptions used in previous research (Tzioumis \& Klapper, 2012; Blouin et al., 2014), which approximates ETR to STR and claims that an increase in ETR contributes to an increase in debt. We consent that in one country setting and absence of change in STR, a relationship between ETR and TDR should be negative (which is not the case in our survey). This is supported by Chen et al. (2010), who claims that compared to the others, companies with more aggressive tax policies demonstrate lower effective tax rates and higher book-tax differences.

Collected evidence leads to the conclusion that, in contrast to Møen et al. (2018), in a small economy like Lithuania, subsidiaries of MNEs do not have a tax advantage over domestic firms, i.e. they are not involved in corporate tax avoidance via debt shifting. Instead, our results confirmed that firm characteristics are the key determinants of the leverage of Lithuanian firms.

The results of our profit shifting model are in line with previous research. Analysis of transfer mispricing across Lithuanian companies proved that tax rate differentials between foreign parents and their Lithuanian subsidiaries strongly influence the earnings of such subsidiaries in the sample. The empirical results are as expected because they are in line with the 'consensus' understanding that transfer pricing manipulation is the dominant corporate tax avoidance channel accounting for $72 \%$ of avoidance cases (Heckemeyer \& Overesch, 2017). There could be several explanations for relatively high compared to other studies semielasticity. For example, subsidiaries of MNEs in small economies can be importers of technology, know-how, other intellectual property, the management or other highly valued services from their parents and which can more easily be subject to transfer mispricing. In addition, this can be supported by the weaknesses of arm's length principle (key dilemma how to price synergies in MNEs global operations) (Luckhaupt et al., 2012), or, alternatively, may be the result of not effective transfer pricing rules or poor quality in tax administration (Dharmapala, 2014).

According to Heckemeyer and Overesch (2017), since the coefficient of tax rate difference to EBIT and EBT are known, there is an alternative option to seize the debt shifting. At the EBT level, the coefficient of tax rate difference is 2.3 , and theoretically, this may involve both debt and profit shifting. The coefficient at the EBIT level is only 1.99, and it may involve profit shifting via transfer pricing manipulation. The difference may be deemed to be debt shifting. But this assumption is not supported by the results of the debt shifting model. We assume that this difference may arise due to misclassification of certain expenses but not because of debt shifting.

Future studies on small open economies should further concentrate on the exploration of effective tax rate differences. Although the effective tax rate is superior to the other tax measures since it combines a statutory tax rate, tax attributes like depreciation rates, investment reliefs, etc. into a single measure; but according to Devereux (2007), the effective tax rate might be an important factor for the initial decision on the investment country, but not for the subsequent decisions regarding the allocation of MNEs taxable income. Based on our current study, we claim that despite its weaknesses, the effective tax rate can be used as a proxy for the tax incentive, but the received results should be confirmed by other tax variables and the direction of impact should be carefully considered. 


\section{Conclusions}

Corporate tax avoidance is the product of globalisation, justified by profit maximisation, and affected by the interaction of uncoordinated tax policy across big and small economies. This paper contributes to evidence of corporate tax avoidance across companies operating in small open economies, discloses a single country's (i.e. Lithuania) tax avoidance practices and adds new insights to the existing literature by exploring more recent periods (2010-2019) data. Results from both debt shifting and profit shifting models proved that in Lithuania, subsidiaries of MNEs engage in corporate tax avoidance via profit shifting channel (transfer mispricing, to be the more precise), while the use of debt shifting channel was not supported by our empirical findings. It could suggest that the statutory tax rate in Lithuania is relatively too low to incentivise multinational tax avoidance via debt.

Our findings show that tax planning is linked with higher profits of sampled MNEs' firms in small open economies, and this supports countermeasures targeting transfer mispricing. Regulatory authorities of small open economies in their oversight role should consider that transfer pricing rules and related tax administration is a strategic decision. Policymakers of small open economies should acknowledge that attracting investments via low tax rates rules are beneficial to such countries because of increased profits and taxes of local subsidiaries of MNEs, but the other (larger) economies would experience a loss of welfare due to the higher taxes and sunk costs in the form of incurred tax planning expenses. On the other hand, as indicated in previous research, countries attempt to enlarge tax revenue via an increase of statutory tax rates would trigger MNEs to decrease their investments in fixed assets or even fully move their FDI to the lower tax countries. From a corporate governance perspective, tax planning may be used as a powerful tool to maximise the value of MNEs and empower effective governance of decentralised affiliates, yet it raises questions regarding the protection of MNEs minority shareholders' rights and fair competition across local and multinational companies.

Better access to firm-level transaction, tax return, tax compliance, corporate governance data would create wider opportunities for deeper corporate tax avoidance research; in addition, an important source for further empirical studies would be to assess the magnitude and effectiveness of anti-avoidance rules in small open economies. This is of utmost importance in the context of the coming global economic crisis, which will contribute to the rise of aggressive tax planning.

The main limitations of this research can be associated with some methodological and sample issues. The sample includes only Lithuanian firms, so it didn't allow to control for any of the country-level variables. Also, there is an unequal distribution of the number of firms in the sample: in domestic firms' sub-sample, it is three times higher than in MNEs firms' subsample. More sophisticated financial data that includes taxation split between profit taxes and deferred taxes, depreciation, internal and external debt was not available, but it would be useful when analysing and interpreting results. All the mentioned factors may lead to biased results of the survey. 


\section{References}

Barion, F., Miniaci, R., Panteghini, P. M., \& Parisi, M. L. (2010). Profit shifting by debt financing in Europe. CESifo Working Paper Series No. 2985.

Bartholdy, J., \& Mateus, C. (2008). Taxes and corporate debt policy: Evidence for unlisted firms of sixteen European countries. Corporate Finance: Capital Structure \& Payout Policies eJournal. https://doi.org/10.2139/ssrn. 1098370

Beer, S., de Mooij, R. A., \& Liu, L. (2018). International Corporate Tax Avoidance: A Review of the Channels, Magnitudes, and Blind Spots. IMF Working Papers, 18(168). https://doi.org/10.5089/9781484363997.001

Blouin, J., Huizinga, H., Laeven, L., \& Nicodème, G. (2014). Thin capitalisation rules and multinational firm capital structure. CESifo Working Paper Series No. 4695. https://doi.org/10.2139/10.2139/ssrn.2379467

Booth, L., Aivazian, V., Demirguc-Kunt, A., \& Maksimovic, V. (2001). Capital structures in developing countries. The Journal of Finance, 56(1), 87-130. https://doi.org/10.1111/0022-1082.00320

Buettner, T., Overesch, M., \& Wamser, G. (2018). Anti profit-shifting rules and foreign direct investment. International Tax and Public Finance, 25(3), 553-580.

Buettner, T., \& Wamser, G. (2013). Internal debt and multinational profit shifting: Empirical evidence from firmlevel panel data. National Tax Journal, 66(1), 63-96. https://doi.org/10.17310/ntj.2013.1.03

Chen, S., Chen, X., \& Cheng, Q., \& Shevlin, T. (2010). Are family firms more tax aggressive than non-family firms? Journal of Financial Economics, 95, 41-61. https://doi.org/10.1016/j.jfineco.2009.02.003

Clausing, K. A. (2016). The effect of profit shifting on the corporate tax base in the United States and Beyond. National Tax Journal, 69(4), 905-934. https://doi.org/10.17310/ntj.2016.4.09

Clausing, K. A. (2009). Multinational firm tax avoidance and tax policy. National Tax Journal, 62(4), 703-725. https://doi.org/10.17310/ntj.2009.4.06

Clausing, K. A. (2003). Tax-motivated transfer pricing and US intrafirm trade prices. Journal of Public Economics, 87(9), 2207-2223. https://doi.org/10.1016/S0047-2727(02)00015-4

Cobham, A., \& Janský, P. (2019). Measuring misalignment: The location of US multinationals' economic activity versus the location of their profits. Development Policy Review, 37(1), 91-110. https://doi. org/10.1111/dpr.12315

Cristea, A. D., \& Nguyen, D. X. (2016). Transfer pricing by multinational firms: New evidence from foreign firm ownerships. American Economic Journal: Economic Policy, American Economic Association, 8(3), 170-202. https://doi.org/10.1257/pol.20130407

De Simone, L. (2016). Does a common set of accounting standards affect tax motivated income shifting for multinational firms? Journal of Accounting and Economics, 61(1), 145-165. https://doi.org/10.1016/j.jacceco.2015.06.002

De Mooij, R. A., \& Hebous,Sh. (2017). Curbing Corporate Debt Bias. IMF working papers, 17(22). https://doi.org/10.5089/9781475573053.001

De Mooij, R., \& Liu. L. (2018). At a cost: The real effects of transfer pricing regulations. IMF Working Paper 18/69. https://www.imf.org/en/Publications/WP/lssues/2018/03/23/At-A-Cost-the-Real-Effects-ofTransfer-Pricing-Regulations-45734 
De Mooij, R., \& Liu, L. (2020). At a cost: The real effects of transfer pricing regulations. IMF Economic Review, 68, 268-306. https://doi.org/10.1057/s41308-019-00105-0

Desai, M. A., Foley, C. F., \& Hines, J. R. (2004). A multinational perspective on capital structure choice and internal capital markets. The Journal of Finance, 59(6), 2451-2487. https://doi.org/10.1111/j.15406261.2004.00706.x

Devereux, M. P. (2007). The impact of taxation on the location of capital, firms and profit: A survey of empirical evidence. Oxford University Centre for Business Taxation Working Paper 07/02. https://core.ac.uk/download/pdf/288286396.pdf

Dharmapala, D. (2014). What do we know about base erosion and profit shifting? A review of the empirical literature. Coase-Sandor Institute for Law \& Economics Working Paper No. 702. https://chicagounbound.uchicago.edu/cgi/viewcontent.cgi?article=2385\&context=law_and_economics

Dischinger, M., Knoll, B., \& Riedel, N. (2014). The role of headquarters in multinational profit shifting strategies. International Tax and Public Finance, 21(2), 248-271. https://doi.org/10.1007/s10797-012-9265-5

Dowd, T., Landefeld, P., \& Moore, A. (2017). Profit shifting of US multinationals. Journal of Public Economics, 148, 1-13. https://doi.org/10.1016/j.jpubeco.2017.02.005

Dwenger, N., \& Steiner, V. (2014). Financial leverage and corporate taxation: Evidence from German corporate tax return data. International Tax and Public Finance, 21(1), 1-10. https://doi.org/10.1007/s10797-0129259-3

Eden, L. (2012). Transfer price manipulation. In P. Reuter (Ed.), Draining development? Controlling flows of illicit funds from developing countries (pp. 205-234). The World Bank.

Egger, P., Eggert, W., Keuschnigg, C., \& Winner, H. (2010). Corporate taxation, debt financing and foreign plant ownership. European Economic Review, 54(1), 96-107. https://doi.org/10.1016/j.euroecorev.2009.06.007

Faccio, M., \& Xu, J. (2015). Taxes and capital structure. Journal of Financial and Quantitative Analysis, 50(3), 277-300. https://doi.org/10.1017/S0022109015000174

Faulkender, M., \& Smith, J. M. (2016). Taxes and leverage at multinational corporations. Journal of Financial Economics, 122(1), 1-20. https://doi.org/10.1016/j.jfineco.2016.05.011

Flaaen, A. (2016). The role of transfer prices in profit-shifting by US multinational firms: Evidence from the 2004 Homeland Investment Act. Finance and Economics Discussion Series 2017-055, Board of Governors of the Federal Reserve System (US). https://doi.org/10.17016/FEDS.2017.055

Frank, M., \& Goyal, V. (2009). Capital structure decisions: Which factors are reliably important? Financial Management, 38, 1-37. https://doi.org/10.1111/j.1755-053X.2009.01026.x

Fuest, C., Hebous, S., \& Riedel, N. (2011). International debt shifting and multinational firms in developing economies. Economics Letters, 113(2), 135-138. https://doi.org/10.1016/j.econlet.2011.06.012

Harris, M., \& Raviv, A. (1991). The theory of capital structure. Journal of Finance, 46, 297-355. https://doi.org/10.1111/j.1540-6261.1991.tb03753.x

Haufler, A., \& Runkel, M. (2012). Firms' financial choices and thin capitalisation rules under corporate tax competition. European Economic Review, 56(6), 1087-1103. https://doi.org/10.1016/j.euroecorev.2012.03.005

Heckemeyer, J. H., \& Overesch, M. (2017). Multinationals' profit response to tax differentials: Effect size and shifting channels. Canadian Journal of Economics, 50(4), 965-994. https://doi.org/10.1111/caje.12283

Heider, F., \& Ljunggvist, A. (2015). As certain as debt and taxes: Estimating the tax sensitivity of leverage from state tax changes. Journal of Financial Economics, 118(3), 684-712. https://doi.org/10.1016/j.jfineco.2015.01.004 
Hines, J. R., Jr., \& Rice, E. M. (1994). Fiscal paradise: Foreign tax havens and American business. The Quarterly Journal of Economics, 109(1), 149-182. https://doi.org/10.2307/2118431

Huizinga, H., Laeven, L. A., \& Nicodeme, G. (2008). Capital structure and international debt shifting. Journal of Financial Economics, 88(1), 80-118. https://doi.org/10.1016/j.jfineco.2007.05.006

Janský, P., \& Planský, M. (2019). Estimating the scale of profit shifting and tax revenue losses related to foreign direct investment. International Tax and Public Finance, 26, 1048-1103 https://doi.org/10.1007/s10797-019-09547-8

Johannesen, N., Tørsløv, T., \& Wier, L. (2016). Are less developed countries more exposed to multinational tax avoidance? Method and evidence from micro-data. WIDER Working Paper No. 2016/10. https://doi.org/10.35188/UNU-WIDER/2016/053-9

Kazmierska-Jozwiak, B., Marszałek, J., \& Sekuła, P. (2015). Determinants of Debt-Equity Choice - Evidence from Poland. EMAJ Emerging Markets Journal, 5(2), 1. https://doi.org/10.5195/emaj.2015.76

Kundelis, E., \& Legenzova, R. (2019). Assessing impact of base erosion and profit shifting on performance of subsidiaries of multinational corporations in Baltic countries. Equilibrium. Quarterly Journal of Economics and Economic Policy, 14(2), 277-293. https://doi.org/10.24136/eq.2019.013

Kundelis, E., Legenzova, R., \& Kartanas, J. (2021). Assessing profit shifting in Lithuanian firms. SHS Web of Conferences, 92. https://doi.org/10.1051/shsconf/20219202037

Lee, B. B., Dobiyanski, A., \& Minton, S. (2015). Theories and empirical proxies for corporate tax avoidance. The Journal of Applied Business and Economics, 17(3), 21-34. http://t.www.nabusinesspress.com/JABE/LeeBB_Web17_3_.pdf

Leszczylowska, A. \& Meier, J. H. (2021). Do earnings stripping rules hamper investment? Evidence from CIT reforms in European countries. Economics Letters, 200(3). https://doi.org/10.1016/j.econlet.2021.109743

Liu, L., Schmidt-Eisenlohr, T., \& Guo, D. (2017). Transfer pricing and tax avoidance: Evidence from linked taxtrade statistics in the UK. Working Paper No. 1715. Oxford University Centre for Business Taxation. https://doi.org/10.2139/ssrn.3009883

Lohse, T., \& Riedel, N. (2013). Do transfer pricing laws limit international income shifting? Evidence from European multinationals. CESifo Working Paper Series No. 4404.

Loretz S., \& Mokkas, S. (2015). Evidence for Profit Shifting with Tax-sensitive Capital Stocks. FinzArchvia 71(1), 1-36. https://doi.org/10.1628/001522115X14206439673251

Luckhaupt, H., Overesch, M., \& Schreiber, U. (2012). The OECD approach to transfer pricing: A critical assessment and proposal. In W. Schön \& K. Konrad (Eds.), Fundamentals of international transfer pricing in law and economics (pp. 91-121). Springer. https://doi.org/10.1007/978-3-642-25980-7_6

Malinic, D., Dencic-Mihajlov, K., \& Ljubenovic, E. (2013). The determinants of capital structure in emerging capital markets: Evidence from Serbia. European Research Studies, XVI(2), 98-119. https://doi.org/10.35808/ersj/391

Mardan, M. (2017). Why countries differ in thin capitalisation rules: The role of financial development. European Economic Review, 91, 1-14. https://doi.org/10.1016/j.euroecorev.2016.09.003

Møen, J., Schindler, D., Schjelderup, G., \& Wamser, G. (2018). The tax-efficient use of debt in multinational $\begin{array}{lllll}\text { corporations. CESifo Working } & \text { Paper }\end{array}$ https://www.econstor.eu/bitstream/10419/181333/1/cesifo1_wp7133.pdf

Møen, J., Schindler, D., Schjelderup, G., \& Tropina, J. (2011). International debt shifting: Do multinationals shift internal or external debt? CESifo Working Paper Series No. 2011-40. http://nbnresolving.de/urn:nbn:de:bsz:352-134678 
Casillo-Murciego, A., \& López-Laborda, J. (2017). Are Spanish companies involved in profit shifting? Consequences in terms of tax revenues. Economics: The Open-Access, Open-Assessment E-Journal, 11(1), 1-47. https://doi.org/10.5018/economicsejournal.ja.2017-1

Nicolay, K., Nusser, H., \& Pfeiffer, O. (2017). On the interdependency of profit shifting channels and the effectiveness of anti-avoidance legislation. ZEW - Centre for European Economic Research Discussion Paper No. 17-066. https://doi.org/10.2139/ssrn.3091567

OECD. (2015). Measuring and monitoring BEPS. OECD/G20 Base Erosion and Profit Shifting Project, Action 11 - 2015 Final Report. http://www.oecd.org/tax/measuring-and-monitoring-beps-action-11-2015-finalreport-9789264241343-en.htm

Rajan, R., \& Zingales, L. (1995). What do we know about capital structure? Some evidence from international data. Journal of Finance, 50(5), 1421-1400. https://doi.org/10.1111/j.1540-6261.1995.tb05184.x

Rego, S. O. (2003). Tax-avoidance activities of US multinational corporations. Contemporary Accounting Research, 20(4), 805-833. https://doi.org/10.1506/VANN-B7UB-GMFA-9E6W

Saunders-Scott, M. J. (2015). Substitution across methods of profit shifting. National Tax Journal, 68, 10991119. https://doi.org/10.17310/ntj.2015.4.09

Tzioumis, K., \& Klapper, L. F. (2012). Taxation and capital structure: Evidence from a transition economy. FinanzArchiv, 68(2), 165-190. https://doi.org/10.1628/001522112X639972

Vicard, V. (2015). Profit shifting through transfer pricing: Evidence from French firm level trade data. Banque de France Working Paper No. 555. https://doi.org/10.2139/ssrn.2614864

Merlo, V., Riedel, N., \& Wamser, G. (2020). The impact of thin-capitalisation rules on the location of multinational firms' foreign affiliates. Review of International Economics, 28(1), 35-61. https://doi.org/10.1111/roie.12440

Wier, L. (2018). Tax-motivated transfer mispricing in South Africa: Direct evidence using transaction data. WIDER Working Paper No. 2018/123. https://www.wider.unu.edu/sites/default/files/Publ ... PDF/wp2018-123_0.pdf

The research article passed the review process | Received: March 21, 2021; Revised: June 26, 2021; Accepted: July 30, 2021; Pre-published online: October 31, 2021; Published in the regular issue: May 19, 2022. 